\title{
The Status Quo and Prospects of the Information Construction of Teaching Management in Colleges and Universities
}

\author{
Ning Chen \\ Shandong University of Finance and Economics, Jinan 250014, Shandong, China \\ Email: 15953100580@163.com
}

\begin{abstract}
With the continuous expansion of colleges and universities in our country, the teaching management of colleges and universities has become more difficult, leading to such a situation: because the number of students is increasing, schools need to increase the management of teacher assignment and student performance. Schools need to invest more manpower for efficient teaching management. In the current information age, advanced information technology is widely used in various fields, which can not only help people reduce working hours, but also effectively improve work efficiency. The use of information technology in university teaching management can achieve good management results. Therefore, based on his own teaching management experience, the author integrates information technology into the current situation of teaching management in colleges and universities, carries out related investigations and proposes reasonable solutions. Keywords: teaching management, colleges and universities, informatization, status quo, development
\end{abstract}

In the context of rapid progress in science and technology, information technology is widely used in people's daily life and work, and has good results. Current information technology has also been gradually applied to education management. Teaching management is the prerequisite and foundation for the normal conduct of all teaching tasks, and is of great significance to the economic benefits and stable development of universities. Applying informatization construction to the management work of colleges and universities can better conform to the development of modern society, and it is also the inevitable development direction of the current education innovation.

\section{The significance of the information construction of teaching management in colleges and universities}

\subsection{Conducive to improving work efficiency}

Under the situation of rapid development of education, the expansion of colleges and universities has also been promoted. As the number of students continues to increase, the task of teaching management has become more and more difficult. At this stage, our country has many shortcomings in the management of colleges and universities. The various links in the work are too detailed and the management process is relatively cumbersome, resulting in unsatisfactory work efficiency. In the process of actual teaching management work, the past information platform was unable to accurately handle various issues, and the work level was not high, and it was difficult to meet its requirements with the continuous improvement of work objectives. But using advanced information technology to carry out teaching management, managers can use the information system to fully understand all the information and data, analyze various basic data, and the method of collecting data in the past is very different. The information system has extremely high accuracy. And it can improve management efficiency to a large extent, laying a solid foundation for subsequent management work ${ }^{[1]}$.

\subsection{Conducive to strengthening teaching management in colleges and universities}

In the past college management work, managers are the core force. In this link, due to various reasons and restrictions, data often inaccurate and other situations. However, the use of advanced information technology can better realize the intensification and networking of management work, apply various information technologies, and be able to intuitively and comprehensively grasp the specific conditions of college students, and then carry out targeted management work. Improve the level and quality of university management, in addition to this, it can also improve the learning level of university students.

\subsection{Conducive to realizing the international interaction of teaching management}

In an era when information technology has not yet been widely popularized, all colleges and universities are unable to conduct timely and effective communication and exchanges due to the geographical location and other reasons. In the 
process of the continuous development of various information technologies, communication and exchanges between all colleges and universities have become more and more frequent, and international interaction has also been implemented to further promote the better development of my country's education. With the application of advanced information technology, different countries can learn from each other in various forms of curriculum, teaching models, and management methods. In addition, it also effectively promotes the sharing of teaching resources. In this process, colleges and universities can grasp the problems in teaching management in a timely manner, and establish reasonable and effective solutions for specific situations, so as to improve the management level.

\section{The status quo of teaching information management in colleges and universities}

\subsection{Incorrect understanding of informatization}

When carrying out teaching management work, informatization construction is cumbersome and complex. Will it have hidden impacts in this process? In all the education links, some university administrators do not fully understand the construction of teaching management informatization. They cannot look at the construction of informatization in a correct and long-term perspective, and cannot carry out scientific and reasonable teaching management. In the education work, too much attention is paid to the investment in hardware facilities, and the importance of software facilities is ignored. Because the management personnel have a wrong understanding of informatization, the informatization construction of education management has been in an immature state for a long time. As a result, the traditional teaching management system of colleges and universities cannot adapt to the development of the times in the actual reform process ${ }^{[2]}$.

\subsection{The overall quality of teaching management staff is not high}

In the context of the rapid progress of information technology, it has also promoted the rapid development of all walks of life, and has also provided very convenient conditions for the teaching management of colleges and universities. The informatization construction of university teaching management has very important significance. However, because of the influence of the educational management concepts in the past, it is relatively easy for the managers of colleges and universities to master their familiar management methods, which is also a challenge to them for new technologies. In order to successfully realize informatization construction, university managers are required to change past management concepts and actively learn new management models. However, some managers do not have sufficient sense of responsibility and innovation in actual work. Under such circumstances, it will definitely cause The efficiency of teaching management has gradually declined, which has caused managers to fail to meet the needs of current university management.

\subsection{Teaching management lacks wholeness}

Teaching management has the characteristics of comprehensiveness, but in fact, according to the overall development of university management, it is not comprehensive, and teaching management information is insufficient. In the process of informatization construction in universities, various problems will inevitably arise, but usually Under the circumstances, university administrators pay too much attention to current problems, lack the awareness of looking at problems through a long-term perspective, and lack sustainable adjustment work. After software facilities have problems, it is difficult to achieve better management and improvement in subsequent work. In the process of constructing teaching management informatization, the lack of unified requirements has resulted in different software used by all departments, and system data cannot be compatible. This situation leads to the inability to share educational information, and errors are likely to occur in the process of information transmission. As a result, various problems have arisen, making the teaching management of colleges and universities more cumbersome ${ }^{[3]}$.

\section{Countermeasures to speed up the construction of teaching management informatization in colleges and universities}

\subsection{Optimize the allocation of campus resources}

In the process of constructing teaching management informatization in colleges and universities, it is necessary to rationally optimize the allocation of teaching resources and implement the effective combination of information and manpower. When configuring information resources, it is necessary to prevent one-time completion. Colleges and universities have many talents and resources. When building schools? It is necessary to make effective use of resources to prevent resource waste due to improper resource allocation. At the same time, in the actual management work, we must strictly implement the humanized management model, adhere to the people-oriented concept, and form a good sense of service and sharing. Only 
in this way can the sustainable development of information management work be realized.

\subsection{Strengthen the construction of software and hardware facilities for education management informatization}

Because our country's colleges and universities are relatively late in launching informatization management work, their development is relatively slow, and they lack good management experience. Therefore, in actual construction, it is necessary to continuously learn advanced construction concepts and successful experiences at home and abroad. At the same time, the educational resources of colleges and universities are limited, and there are not enough funds to support the construction of information management, so funds can be raised through diversified platforms. Actively implement preferential policies to encourage local governments and enterprises to actively participate in the construction of informatization teaching management, actively introduce various new technologies and construction funds, and continuously innovate software and hardware facilities to create sufficient material guarantee for informatization construction. In addition, it is necessary to build a relatively stable school network to provide solid conditions for the school's application information platform ${ }^{[4]}$.

\subsection{Increase the emphasis on management}

Because in the process of gradual transformation of education work to informatization, the inherent teaching management model has not been in line with the current education work and education system, and to a certain extent has affected the smooth development of school teaching management. Colleges and universities need to increase their awareness of management work, strengthen the training of managers, improve their professional knowledge and management level, and truly realize the joint development of technology and systems. The management of colleges and universities has gradually become the core content of the smooth development of learning, which can not only better maintain the teaching work, but also effectively improve the overall strength of the colleges and universities.

\section{Conclusion}

In the context of continuous optimization and innovation of the educational system of colleges and universities, managers must actively improve the level of teaching management, improve the overall teaching level of colleges and universities through management informatization, and reduce the rate of repetitive labor and resource consumption. Achieving the informatization of teaching management can promote mutual coordination among all departments of the university, enhance the standardization of management work and the sense of responsibility of management personnel, and strengthen the interaction between all departments and avoid conflicts. In the construction of teaching management informatization, the educational administration management system has a very important position, which can have a decisive influence on the management level of colleges and universities.

\section{References}

[1] Liu Bo. Discussion on the status quo and development trend of teaching management informatization in colleges and universities[J]. Science and Technology Information. 2020; 18(12): 143-144.

[2] Guo Ting. On the status quo and development trend of the information construction of teaching management in colleges and universities[J]. Chinese Information. 2019; (8): 113-113.

[3] Zhang Tingting. Analysis of the status quo and countermeasures of the information construction of the educational administration management system in colleges and universities[J]. Journal of Jiamusi Vocational College. 2019; (1): 108-109.

[4] Xu Zhijuan. Analysis of the status quo of teaching management and platform construction in colleges and universities under the conditions of informationization[J]. Modern Vocational Education. 2020; (48): 198-199. 